\title{
Instructional Materials as Correlates of Students' Academic Performance in Biology in Senior Secondary Schools in Osun State
}

\author{
Bisiriyu Ajani Awolaju
}

\begin{abstract}
The study investigated instructional materials as correlates of students' academic performance in Senior Secondary Schools in Osun State. The sample used for the study consisted of 40 students who were randomly selected from two different secondary schools in Ilesa East Local Government area in Osun State. 20 Students were used for experimental group while the other 20 students were under the control group. Quantitative method was used to collect data by using the research questions and hypotheses formulated for the study. Research instrument used for the study consisted of Biology Achievement Test (BAT). This BAT contained a 50 multiple choice items. A reliability coefficient of 0.82 was obtained for BAT, using Test-retest method. Data collected were analysed by using mean score, standard deviation and $T$-test distribution. Findings revealed that students taught with instructional materials performed better than those taught without instructional materials. That is the experimental group performed better than the control group ( $t$-calculated value, $3.94>t$-critical value 2.02). It was further revealed that there is no significant difference between pre-test scores and post- test scores of experimental group ( $t$-critical value, $2.02>$ $t$-calvalue-2.79). The post test scores of male and female students taught with instructional materials showed no significant difference between their scores ( $t$-critical value, $2.10>$ $t$-calculated value, 1.33). Based on these findings appropriate recommendations were made.
\end{abstract}

Index Terms-Academic performance, instructional materials, biology, secondary school students, Osun State.

\section{INTRODUCTION}

The search for efficient and effective delivery of instruction to students has always been major concern of science educators. This is so as a result of repeated mass failure recorded in West African senior secondary school examination (WASSCE). Among other factors that could be responsible for this failure, are the instructional materials which definitely must have a significant role to play in teaching and learning processes. Instructional materials are defined by different authors though they convey the same meaning when interpreted. Instructional material could be explained as devices through which knowledge, skills, attitude, ideas, beliefs and values got transmitted to the learner by the teacher in order to ease teaching-learning process. Akanbi [1] defined instructional materials as materials designed to enrich the teaching and learning processes and hence contribute to better learning. Leohard [2],

Manuscript received November 27, 2014; revised March 13, 2015.

B. A. Awolaju is with the Department of Biology, Osun State College of Education, Ilesa, Nigeria (e-mail: bisiriyuajani@gmail.com). conceived instructional materials as "a wide range of materials and devices, designed to provide realistic imagery and substitute experiences in order to enrich curricular experiences of many kinds". From the afore mentioned meanings of instructional materials, the best way of helping pupils to learn is to bring them face to face with the world which education intends to introduce to them (Mkpa, [3]). He stressed further that one way this can be attained is by using real objects in real life situations for instruction. Where real life situation are not possible, the alternative is for the teacher to use representations of real life situations. These representations are materials, devices and techniques that help the teacher to make realistic approach to his job. Whether real or substitutes, these representations have a common goal. They help the teacher to convey the intended message effectively and meaningfully to the learners so that the learners receive, understand, retain and apply the experience gained to reach overall educational goals. Some authors have written to classify the types of instructional materials that may be used in teaching and learning (Ezegbe, [4], Adjai, [5] Ukeje, [6]).

Generally, according to the classifications, we have audio-aids-those resources that appeal to the sense of hearing only; visual aids-those that appeal to the sense of sight only; and audio-visual aids-those that appeal to both senses of hearing and sight at the same time. While some of these materials are difficult to procure, on account of their cost and availability, many can be improvised by the resourceful leader.

The importance of instructional materials in teaching and learning is too obvious to be overemphasized. A lot has been written to show the indispensable role of materials in curricular implementation (Onyejemezi, [7], Ogunranti, [8], Afolaju, [9]). These authors points out that instructional materials increase the rate of learning; save the teacher time and effort, increase learners interest and facilitate retention of what is learned. In addition to the latter statement, Akinfe, Olofinniyi, Fashiku [10], stated that the use of instructional materials in teaching process is less stressful for both teacher and students. To further show the importance of instructional materials, Jegede, Okota, Eniayelu [11], reported factors responsible for poor performance in science, technology and mathematics which include poor laboratory facilities, inappropriate teaching methods and inadequate number of learning facilities in schools as against consistent increase in number of students. In condition of insufficient supply of instructional materials by the government, improvised materials can also swerve similar role of simplifying explanations given by teachers. Improvisation of instructional 
materials needs the effort of Biology teacher for its realisation. Bassey [12] and Omosewo [13] considered the human factors as the teacher's professional commitment, creativity, mechanical skills, initiative and resourcefulness. They stated that many Nigerians science teachers were aware of possibility of improvisation. They also noted that few teachers practise while majority depends on imported equipment and claim that improvisation is time consuming and often depleting. These authors also noted that students possessed little or no interest in improvisation.

Whether instructional materials are classified as improvised or imported, the most important effect of these materials is to assist in achieving the stated behavioural objectives when evaluation is carried at the end of a lesson or programme.

\section{A. Statement of Problem}

With regard to different views held on importance of instructional materials by different authors and the observed progressive decline in secondary school students' academic performance in West African Senior School Certificate Examination (WASSCE), there is need to further investigate the roles of instructional materials on the academic performance of senior secondary school students in Ilesa East Local Government Area of Osun State, Nigeria.

\section{B. Research Questions}

1) Do students perform better taught with instructional materials than those taught without instructional materials?

2) Is there any significant difference between pre-test scores and post-test scores of student taught with instructional material?

3) Is there any significant difference between the post-test scores of male and female students taught with instructional materials?

\section{Research Hypotheses}

In addition to the research questions, the following hypotheses were formulated and tested:

1) There is no significant difference between students taught with instructional materials and those taught without instructional materials.

2) There is no significant difference between pre-test scores and post - test scores of students taught with instructional materials.

3) There is no significant difference between post - test scores of male and female students taught with instructional materials.

\section{MethodOlOGY}

\section{A. Population and Sample}

Population of this study consisted of senior secondary school students in Ilesa East Local Government Area of Osun State. From this population, a sample of 40 students was selected for this study.

\section{B. Research Instrument}

The research instrument used for this study consisted of
Biology Achievement Test (BAT). This BAT contained 50 multiple choice items with option A - D. A reliability co-efficient of 0.82 was obtained for the BAT by using Test-retest method. This was administered to students in the experimental and control groups before and after treatment. That is, pre - test and post-test were administered to these two groups of students.

\section{Method of Data Analysis}

The mean score, standard deviation and $t$-test distribution were used to compute the data collected from the selected sample. All hypotheses were tested at 0.05 level of significance or $95 \%$ certainty of prediction.

\section{RESULTS}

The results obtained from the study are as shown in the following tables:

Table I shows $t$-test statistics of significant difference between the academic performance of students taught with instructional material and those taught without instructional material.

TABLE I: $T$-TEST STATISTICS OF SigNIFICANT DifFERENCE BETWEEN THE

\begin{tabular}{|l|l|l|l|l|}
\hline \multicolumn{5}{|c|}{ ACADEMIC PERFORMANCE } \\
\begin{tabular}{|l} 
Category of \\
students
\end{tabular} & Mean & $\begin{array}{l}\text { Standard } \\
\text { Deviation }\end{array}$ & $\begin{array}{l}\text { Calculated } \\
t \text { value }\end{array}$ & $\begin{array}{l}\text { Critical } \\
t \text { value }\end{array}$ \\
\hline $\begin{array}{l}\text { Students taught } \\
\text { with instructional } \\
\text { material }\end{array}$ & 34.25 & 5.92 & 3.94 & 2.02 \\
\hline $\begin{array}{l}\text { Students taught } \\
\text { without } \\
\text { instructional } \\
\text { material }\end{array}$ & 27.8 & 4.30 & - & - \\
\hline $\begin{array}{l}\text { d.f }=38 \\
\text { level of significance: } 0.05\end{array}$ & & & \\
\hline
\end{tabular}

Table II shows $t$-test statistics of significant difference between pre-test and post test scores of students taught with instructional materials.

TABLE II: $T$-TEST STATISTICS OF SIGNIFICANT DIFFERENCE BETWEEN

\begin{tabular}{|l|l|l|l|l|}
\hline $\begin{array}{l}\text { Types of } \\
\text { test scores }\end{array}$ & Mean & $\begin{array}{l}\text { Standard } \\
\text { Deviation }\end{array}$ & $\begin{array}{l}\text { Calculated } \\
t \text {-value }\end{array}$ & $\begin{array}{l}\text { Critical } \\
t \text {-value }\end{array}$ \\
\hline $\begin{array}{l}\text { Pre-test } \\
\text { scores }\end{array}$ & 28.15 & 7.85 & -2.79 & 2.02 \\
\hline $\begin{array}{l}\text { Post-test } \\
\text { scores }\end{array}$ & 34.25 & 5.3 & & \\
$\begin{array}{l}\text { d.f }=38 \\
\text { Level of significance: } 0.05\end{array}$
\end{tabular}

Table III shows $t$-test statistics of significant difference between post-test scores of male and female students taught with instructional materials.

TABLE III: $T$-TEST STATISTICS OF SigNIFICANT DIFFERENCE BETWEEN POST

\begin{tabular}{|c|c|c|c|c|}
\hline $\begin{array}{l}\text { Gender } \\
\text { post test } \\
\text { scores }\end{array}$ & Mean & $\begin{array}{l}\text { Standard } \\
\text { Deviation }\end{array}$ & $\begin{array}{l}\text { Calculated } \\
t \text {-value }\end{array}$ & $\begin{array}{c}\text { Critical } \\
t \text {-value }\end{array}$ \\
\hline Male & 35.8 & 4.90 & & \\
\hline $\begin{array}{l}\text { Female } \\
\text { students }\end{array}$ & 32.7 & 5.48 & 1.33 & 2.10 \\
\hline
\end{tabular}




\section{DISCUSSION}

Table I shows that calculated $t$ value (3.94) is greater than critical $-t$ value (2.02). This implies that there is significant difference between academic performances of students taught with instructional materials compared with those taught without instructional materials. The significant difference shown by the experimental group over the control group could be directly linked to the application of instructional materials which facilitated learning among students constituting the group. The result of the study was similar to the view held by MKpa [3] in which he referred to instructional materials as devices that help the teacher to convey the intended message effectively and meaningfully to the learners so that the learners receive, understand, retain and apply the experience gained to reach overall educational goals Hence, the experimental group performed better than the control group. The control group was not exposed instructional materials during teaching-learning process, has also proven by Danmole and Lameed [14].

Table II shows that there is no significant difference between the pre-test and post-test scores of students taught with instructional materials. The hypothesis was accepted on the fact that the use of instructional materials had further enhanced the acquisition of knowledge imparted the students. The mean scores of post test score (34.25) of these students taught with instructional material was higher compared with their pre test scores (28.15); though no significant differences was recorded between both scores (i.e pre-test and post-test scores).

With regard to gender, the result got from analyzed data indicated no significance in the achievement of male and female students in biology, when taught with instructional materials (Table III), calculated $-t$ value $(2.10)>$ critical $-t$ value (1.33). This finding is similar to the findings that had shown causal links between instructional strategies and achievement in science and biology (Danmole and Adeoye, [15], Danmole and Adebayo, [16], Zywica and Gomez, [17], Lameed, [18]).

This finding is also similar that of Bassey [5], who also found that there was no significant effect of gender on students' achievement in physics. The result revealed by this study, implies that both male and female students achieved equally under the same condition during learning and teaching process, since achievement has to do with mental and intellectual ability and not gender, it could be deduced that there was no significant interaction effect of treatment (instructional materials) and gender on student achievement in Biology.

\section{CONCLUSION}

The role of instructional materials if thoroughly considered cannot be either partially or totally isolated from teaching-learning process. For any meaningful educational programme to be achieved in terms of its implementation, the aspect of instructional materials must be given serious priority Instructional materials perform such function as the extension of the range of experience available to learners, supplement and complement the teacher's verbal explanations thereby making learning experience richer and providing the teacher with interest into a wide variety of learning activities.

To boost the attainment of objectives of teaching a subject matter, it behaves on Biology teacher to assist his teaching with appropriate instructional material that will enable him/her to achieve his/her objectives and this improves academic achievement of the students taught.

\section{RECOMMENDATION}

Considering the results got from the study, the following recommendations are hereby suggested:

1) Teachers should be encouraged to make use of different instructional materials as long as they are relevant to their lesson contents

2) In case these instructional materials are not available, government should assist schools financially so that these teaching aids are purchased.

3) A situation where ready - made instructional materials are insufficient, these should be supplemented with improvised instructional materials.

4) For any teacher to make use of improvised instructional materials there is need for such teacher to be resourceful in material selection and planning.

5) Government should assist schools by organizing seminars and workshops for Biology teachers to enrich their knowledge about improvisation.

6) Government should periodically check the instructional materials supplied to schools through the Education inspectors to ensure proper use of these materials.

\section{ACKNOWLEDGMENT}

B. A. Awolaju thanks the Federal Ministry of Education for giving financial support through TETFUND (Tertiary Education Trust Fund) to ensure oral presentation and publication of this paper. I also thank the Dean, School of Science, (Canon 'Posi Aduroja) and other senior colleagues, Dr. R. O. Bolarinwa, and Dr. Femi Esan for the encouragement and financial supports towards achieving success in this publication.

\section{REFERENCES}

[1] M. A. Mkpa, "Status of implementation of the national policy as it relates to instructional materials," Nigeria Educational Research Association (NERA), pp. 253-261, 1989.

[2] M. P. Bassey, "Availability of resources for the teaching of science in public secondary schools," J. Afri Edu, vol. 1, pp. 29-36, 2005.

[3] I. A. Omosewo, Vocational Education in Nigeria, Lagos, Longman Publication, 1980.

[4] L. Afolaju," Enhancing children education through illustration," Daily Times, Lagos, January 31st, 1987.

[5] K. Akanbi, Selection, Utilization and Evaluation of Instructional Media, 2nd ed., Y Books Press, Ibadan, 1988, p. 15.

[6] J. Zywica and K. Gomez, "Annotaing to support learning in content areas: Teaching and learning science," Journal of Adolescent and Adult Literature, vol. 52, no. 2, 2008.

[7] B. T. Danmole and S. A. Adebayo, "Effect of concept mapping on student academic performance in junior secondary school integrated science in Ilorin Metropolis," African Journal of Education Studies, vol. 3 , no. 1, pp. 249-266, 2005.

[8] B. T. Danmole and S. N. Lameed. "Exploring annotated drawing for improving Nigerian secondary school students achievement in genetics," International Journal of Biology Education, vol. 3, no. 1, March, 2014. 
[9] P. Leohard, Physical Education in Secondary Schools, 3rd ed., New York Grow-Hill Books Company, New York, 1999, pp. 30-32.

[10] M. O. Ezegbe, Teaching Social Studies in Nigeria Schools and Colleges, Owerri Diocessan Press, 1979.

[11] E. Akinfe, O. E. Olofinniyi, and C. O. Fashiku, "Teachers' quality as correlates of students academic performance in biology in senior secondary schools of Ondo State, Nigeria," Online Journal of Education Research, vol. 1, no, 6, pp. 108-114, 2012.

[12] R. Adjai, Principles and Practice of Teaching, London: George Allen \& Unwin Ltd., 1980.

[13] B. T. Danmole and A. Femi, "Effect of concept mapping technique on senior secondary school students' achievement and retention of ecology concepts," Journal of the Science Teacher Association of Nigeria, vol. 39, no. 1-2, 2004

[14] P. Ogunranti, "Educational technology," A.C.E. Series University of Ibadan, Ibadan, Heinemann Educational Books (Nigeria) Ltd., 1982.

[15] D. A. Onyejemezi, "Curriculum materials," in U. Onwuka, Ed., Curriculum Development for Africa, Onitsha, African Fed Publisher Ltd. Onitsha, 1981

[16] B. O. Ukeje, "Educational technology in Nigeria education," presented at the First Annual Conference of the Nigerian Association of Education Technologists, University of Nigeria, Nsukka, July 6-9, 1986.

[17] S. N. Lameed, "The use of guide discovery and its effect on the performance of students in biology," M.ED project, Department of Curriculum Studies, Lagos State University, 2002.
[18] O. J. Jegede, O. E. Okota, and P. A. Eniayelu, "Raising the standard of performance in public examination in science, technology and mathematics," Science Teachers Association of Nigeria (STAN), 1992.

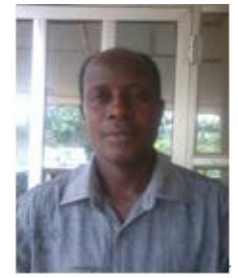

Bisiriyu Ajani Awolaju was born in Ile-Ife, Osun state, Nigeria on June 29,1962 . He received his B.Ed in biology education, University of Benin, Benin City, Nigeria, in 1991, and the PGD in medical microbiology from Federal University of Technology Akure, Nigeria, in 2004, and the M.Sc. in zoology, parasitology option, University of Ibadan, Ibadan, Nigeria, 2006.

$\mathrm{He}$ is a principal lecturer at Osun State College of Education, Ilesa, Nigeria and has already spent 19 years in the institution. He was the former Ag. HOD in Biology Department and currently he is the assistant dean I, U Bed Directorate an affiliated Degree Programme of University of Ibadan, Osun State College of Education Centre. He has some published papers in both local and International Journals.

Mr. Awolaju is a member of Zoological society of Nigeria and a member of Teacher Registration Council of Nigeria (TRCN). No. of Certificate: OS/T/OO165. 